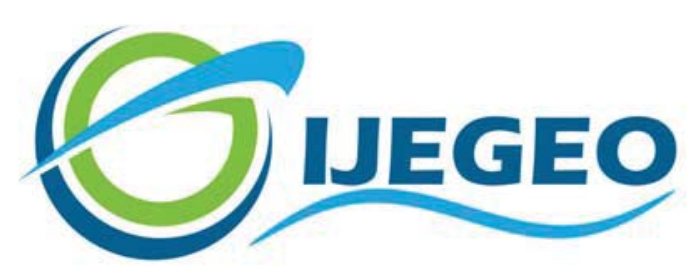

International Journal of Environment and Geoinformatics (IJEGEO) is an international, multidisciplinary, peer reviewed, open access journal.

\title{
The Importance of Corrosion Protection of Metal-Containing Historical Artifacts and Common Methods Used for Preservation
}

\section{Gül Merve GENÇER}

\author{
Chief in Editor \\ Prof. Dr. Cem Gazioğlu \\ Co-Editors \\ Prof. Dr. Dursun Zafer Şeker, Prof. Dr. Şinasi Kaya, \\ Prof. Dr. Ayşegül Tanık and Assist. Prof. Dr. Volkan Demir
}

Editorial Committee (December 2021)

\begin{abstract}
Assoc. Prof. Dr. Abdullah Aksu (TR), Assit. Prof. Dr. Uğur Algancı (TR), Prof. Dr. Bedri Alpar (TR), Assoc. Prof. Dr. Aslı Aslan (US), Prof. Dr. Levent Bat (TR), Prof. Dr. Paul Bates (UK), İrşad Bayırhan (TR), Prof. Dr. Bülent Bayram (TR), Prof. Dr. Luis M. Botana (ES), Prof. Dr. Nuray Çağlar (TR), Prof. Dr. Sukanta Dash (IN), Dr. Soofia T. Elias (UK), Prof. Dr. A. Evren Erginal (TR), Assoc. Prof. Dr. Cüneyt Erenoğlu (TR), Dr. Dieter Fritsch (DE), Prof. Dr. Çiğdem Göksel (TR), Prof.Dr. Lena Halounova (CZ), Prof. Dr. Manik Kalubarme (IN), Dr. Hakan Kaya (TR), Assist. Prof. Dr. Serkan Kükrer (TR), Assoc. Prof. Dr. Maged Marghany (MY), Prof. Dr. Michael Meadows (ZA), Prof. Dr. Nebiye Musaoğlu (TR), Prof. Dr. Masafumi Nakagawa (JP), Prof. Dr. Hasan Özdemir (TR), Prof. Dr. Chryssy Potsiou (GR), Prof. Dr. Erol Sarı (TR), Prof. Dr. Maria Paradiso (IT), Prof. Dr. Petros Patias (GR), Prof. Dr. Elif Sertel (TR), Prof. Dr. Nüket Sivri (TR), Prof. Dr. Füsun Balık Şanlı (TR), Prof. Dr. Uğur Şanlı (TR), Duygu Ülker (TR), Prof. Dr. Seyfettin Taş (TR), Assoc. Prof. Dr. Ömer Suat Taşkın (TR), Assist. Prof. Dr. Tuba Ünsal (TR), Dr. Manousos Valyrakis (UK), Dr. İnese Varna (LV), Dr. Petra Visser (NL), Prof. Dr. Selma Ünlü (TR), Assoc. Prof. Dr. Oral Yağcı (TR), Prof. Dr. Murat Yakar (TR), Assoc. Prof. Dr. İ. Noyan Yılmaz (AU); Assit. Prof. Dr. Sibel Zeki (TR)
\end{abstract}

Abstracting and Indexing: TR DIZIN, DOAJ, Index Copernicus, OAJI, Scientific Indexing Services, International Scientific Indexing, Journal Factor, Google Scholar, Ulrich's Periodicals Directory, WorldCat, DRJI, ResearchBib, SOBIAD 
Review Article

\title{
The Importance of Corrosion Protection of Metal-Containing Historical Artifacts and Common Methods Used for Preservation
}

\author{
Gül Merve Gençer ${ }^{1,2}$ \\ ${ }^{1}$ Department of Chemistry, Faculty of Science, Akdeniz University, 07058, Antalya, Turkey \\ ${ }^{2}$ BelenMed R\&D Ltd., Antalya Technopolis, Akdeniz University, 07985, Antalya, Turkey \\ E-mail: gulmervekurtbelen@gmail.com
}

Received 14.04.2021

Accepted 23.08.2021

How to cite: Gençer (2021). The Importance of Corrosion Protection of Metal-Containing Historical Artifacts and Common Methods Used

for Preservation, International Journal of Environment and Geoinformatics (IJEGEO), 8(4):514-520. DOI: 10.30897/ijegeo.915698

\begin{abstract}
Metal objects were used for various purposes like in the production, decoration, and painting of metallic coins, kitchenwares, and as structural components from ancient ages to the present. Metal extraction and processing ability became one of the important factors to determine the development level of society. For this reason, repairing and protecting the ancient artifacts buried underground or in an aqueous environment that recovered from the archaeological excavations and historical sites is extremely important to protect the history and cultural heritage of society. Historical artifacts are very fragile against environmental factors after their removal from the dig sites and thus rapid intervention procedures are required. Furthermore, historical artifacts exhibited without an application of a protective coating can easily corrode at an increased rate against atmospheric conditions over time. Therefore, developing new approaches for the preservation of metallic objects of cultural heritage has significant importance. It is necessary to know the type of metal to be processed as the coating to be developed for protection will be determined according to the type of metal. Primarily, metal surfaces must be cleansed from the corroded layer followed by developing and applying a structure able to isolate the metal from the environment in order to prevent corrosion. Various materials such as waxes, oils and greases, polymers, glasses and glassy enamels, metallic, and organic coatings have been used to develop corrosion-resistant coatings. Soluble corrosion inhibitors have also been used, which can promote the spontaneous formation of a protective barrier film on surfaces. The structures to be used in the protection of the ancient artifacts must have specific features:

- must not cause a change in color and has to preserve authenticity in visual appearance,

- easy to apply,

- low cost,

- reversibility in some cases, i.e. easy to remove from the surface,

- environmentally friendly, non-toxic.

In this review, the methods commonly used for the protection of archaeological artifacts are examined and their advantages and disadvantages are stated.
\end{abstract}

Keywords: Historical artifact, Protection, Repair, Surface coating technologies, Corrosion, Anti-corrosion coatings

\section{Introduction}

Metal mining capabilities and the use and protection of metals are the most important aspects that show the development level of civilizations since prehistoric times. Metals were widely used in ornaments, coins, military items, kitchen tools, various containers developed for carrying liquids, etc. However, metal surfaces can corrode depending on the environmental conditions that make them vulnerable, although they are extremely durable mechanically. These metal objects form different minerals in the presence of various substances such as water, oxygen, chlorine, and sulfur in the environment, depending on the elements in their structure. In terms of thermodynamics, it is impossible to completely prevent these transformations. Nevertheless, different kinds of applications were made throughout history in order to slow down the deterioration such as forming different metal alloys and surface protective coating with materials like oil, wax, and glass.
The structures to be used in the protection of the ancient artifacts must have specific features: must not cause a change in color and has to preserve authenticity in visual appearance, easy to apply, low cost, reversibility in some cases, environmentally friendly and non-toxic.

In this review, the methods commonly used for the protection of archaeological artifacts are examined and their advantages and disadvantages are stated.

\section{Properties of metal-containing historical artifacts}

Many objects exhibiting in museums are made of metals and metal alloys or have metal parts and engravings. Corrosion occurring as a result of various reasons on the surfaces of these historical artifacts makes it vulnerable to threats such as discoloration, loss of material, etc., and thermodynamically, metal-containing surfaces are inclined to corrode. These surfaces degrade over time depending on the exposure to light, temperature changes, relative humidity cycles, the chemical structure of the 
environment (acidic, basic medium, salt content, etc.), insects, and microorganisms. Degradation can penetrate towards the interior of the artifact but the first point of attack is undoubtedly the surface where the object is exposed to the external environment.

Artifacts start to deteriorate even if they are only exposed to the atmosphere because of the formation of nano or micro-degradation layers with different chemical composition and their easy adsorption to the surface (Figure I). The interaction mechanism and kinetics of these harmful compounds depend on the physical and chemical structures of the surfaces. Appropriate conservative intervention can only be done if the chemical structure of the metal and the medium and the mechanism of interaction of these surfaces is known. Although it has been used frequently in the many fields of science and technology and has been covered in many books and papers (Lyklema 2001, Kolasinski 2012) for a long time, the importance of surface science in the restoration and preservation of historical artifacts has generally been underestimated. General preservation methods used today mostly consist of patination techniques and paint or varnish applications lacking a detailed examination of the surface properties. These methods can't be applied to historical materials and museum items since they can't guarantee to preserve the authenticity of the material (Black 1999). It is important that historical artifacts are repaired and preserved as sensitive as possible with easily applicable and recyclable methods. In addition, low-cost materials should be preferred for various reasons such as limited museum budgets for conservation and repair, a large amount of use especially for large-size artifacts recovered from underwater.

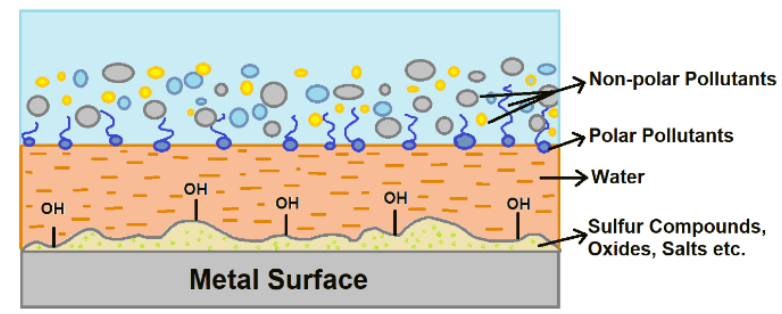

Fig.1. Layers formed on the corroded metal surface

\section{Types of Corrosion On Metal Surfaces And Causative Factors}

The structure of the surface and related chemical reactions that may occur has to be known in order to stop or slow down the corrosion process. The corrosion process transforms into different species under the influence of other environmental factors in accordance with the type of metal or alloy used in the artifact. The resulting products often further catalyze these transformations leading to the complete destruction of the material. Protection and preservation can only be achieved with an understanding of the mechanisms that cause corrosion in this process. Corrosion is briefly defined as the deterioration of metals due to an electrochemical process. Formation of rust on iron, darkening of silver and blue-green patina occurring on copper are some examples of corrosion. Table 1 shows the compounds formed by corrosion of different metal surfaces and their properties.

Table 1. Types and properties of corrosion on different metal surfaces

\begin{tabular}{|c|c|c|c|}
\hline Metal & $\begin{array}{l}\text { Chemical Formula } \\
\text { Resulting From } \\
\text { Corrosion }\end{array}$ & Color & $\begin{array}{l}\text { Mineralogical } \\
\text { Name }\end{array}$ \\
\hline \multirow{5}{*}{$\begin{array}{l}\text { Iron } \\
(\mathrm{Fe})\end{array}$} & $\begin{array}{l}\mathrm{Fe}_{2} \mathrm{O}_{3} \cdot \mathrm{H}_{2} \mathrm{O} \\
\alpha-\mathrm{FeO}(\mathrm{OH})\end{array}$ & $\begin{array}{l}\text { Red brown } \\
\text { Yellowish to } \\
\text { reddish to dark } \\
\text { brown or black }\end{array}$ & a-form hematite \\
\hline & $\mathrm{Fe}_{3} \mathrm{O}_{4}$ & Black & $\begin{array}{l}\text { Magnetite / } \\
\text { lodestone }\end{array}$ \\
\hline & $\mathrm{Fe}(\mathrm{OH})_{2}$ & Blue/green & $\begin{array}{l}\text { soluble, the color } \\
\text { going from } \\
\text { yellow to green } \\
\text { and blue by } \\
\text { changing the pH } \\
\text { of the solution }\end{array}$ \\
\hline & $\mathrm{FeO}$ & Black & $\begin{array}{l}\text { Wüstite, } \\
\text { Pyrophoric }\end{array}$ \\
\hline & $\begin{array}{l}\left(\mathrm{Fe}^{3+} \mathrm{Ni}^{2+}\right)_{8}(\mathrm{OH}, \mathrm{O})_{16} \mathrm{Cl}_{1.25} \\
\cdot \mathrm{nH}_{2} \mathrm{O}\end{array}$ & $\begin{array}{l}\text { Yellowish brown, } \\
\text { rusty brown }\end{array}$ & Akaganeite \\
\hline \multirow{5}{*}{$\begin{array}{l}\text { Copper } \\
(\mathrm{Cu})\end{array}$} & $\mathrm{Cu}_{2} \mathrm{O}$ & Red & Cuprite \\
\hline & $\mathrm{CuO}$ & Black & Tenorite \\
\hline & $\mathrm{Cu}_{2} \mathrm{CO}_{3}(\mathrm{OH})_{2}$ & Green & Makachite \\
\hline & $\mathrm{Cu}_{2}\left(\mathrm{CO}_{3}\right)_{2}(\mathrm{OH})_{2}$ & Blue & Malachite \\
\hline & $\mathrm{Cu}_{3}\left(\mathrm{CO}_{3}\right)_{2}(\mathrm{OH})_{2}$ & Dark to pale blue & Azurite \\
\hline \multirow{2}{*}{$\mathrm{Cu} / \mathrm{Cl}$} & $\mathrm{CuCl}$ & White & Nantokite \\
\hline & $\mathrm{Cu}_{2} \mathrm{Cl}(\mathrm{OH})_{3}$ & Bright green & Atacamite \\
\hline \multirow{3}{*}{$\mathrm{Cu} / \mathrm{S}$} & $\mathrm{Cu}_{2} \mathrm{~S}$ & $\begin{array}{l}\text { Dark gray to } \\
\text { black }\end{array}$ & Chalcocite \\
\hline & $\mathrm{CuS}$ & $\begin{array}{l}\text { Indigo-blue or } \\
\text { darker }\end{array}$ & Covellite \\
\hline & $\mathrm{Cu}_{4} \mathrm{SO}_{4}(\mathrm{OH})_{6}$ & Green & Brochantite \\
\hline \multirow[b]{2}{*}{$\begin{array}{l}\text { Silver } \\
(\mathrm{Ag})\end{array}$} & $\mathrm{Ag}_{2} \mathrm{~S}$ & Iron color-black & Acanthite \\
\hline & $\mathrm{AgCl}$ & $\begin{array}{l}\text { Green, light } \\
\text { yellow, light } \\
\text { green, grey, } \\
\text { violet-brown on } \\
\text { exposure to light }\end{array}$ & Chlorargyrite \\
\hline \multirow{2}{*}{ Tin $(\mathrm{Sn})$} & $\mathrm{SnO}$ & $\begin{array}{l}\text { Black or red } \\
\text { powder when } \\
\text { anhydrous, white }\end{array}$ & $\begin{array}{l}\text { Tin(II) oxide, } \\
\text { stannous oxide }\end{array}$ \\
\hline & $\mathrm{SnO}_{2}$ & $\begin{array}{l}\text { Black, brown, } \\
\text { red, yellow, gray, } \\
\text { white; rarely } \\
\text { colorless }\end{array}$ & Cassiterite \\
\hline \multirow{7}{*}{$\begin{array}{l}\text { Lead } \\
(\mathrm{Pb})\end{array}$} & $\mathrm{PbO}$ & Red & Litharge/massicot \\
\hline & $\mathrm{PbO}_{2}$ & $\begin{array}{l}\text { Dark reddish } \\
\text { brown }\end{array}$ & Scrutinyite \\
\hline & $\mathrm{Pb}(\mathrm{OH})_{2}$ & white & $\begin{array}{l}\text { Hydroxide of } \\
\text { lead }\end{array}$ \\
\hline & $\mathrm{Pb}_{5} \mathrm{O}(\mathrm{OH})_{2}\left(\mathrm{CO}_{3}\right)_{2}$ & $\begin{array}{l}\text { Colorless, White, } \\
\text { Gray }\end{array}$ & Plumbonacrite \\
\hline & $\mathrm{Pb}_{3}(\mathrm{OH})_{2}\left(\mathrm{CO}_{3}\right)_{2}$ & White or gray & Hydrocerussite \\
\hline & $\mathrm{PbSO}_{4}$ & $\begin{array}{l}\text { Colorless to } \\
\text { white, commonly } \\
\text { tinted gray }\end{array}$ & Anglesite \\
\hline & $\mathrm{PbCO}_{3}$ & $\begin{array}{l}\text { Colorless, white, } \\
\text { gray, blue, or } \\
\text { green }\end{array}$ & Cerussite \\
\hline $\begin{array}{l}\text { Zinc } \\
(\mathrm{Zn})\end{array}$ & $\mathrm{ZnO}$ & $\begin{array}{l}\text { Orange, yellow- } \\
\text { orange }\end{array}$ & Zincite \\
\hline
\end{tabular}

Since ancient times, metal items containing copper have been widely used. Bronze, an alloy consists of copper and tin, was used frequently in the production of everyday items such as coins, plates, bowls, weapons, etc. and for this reason, most of the archaeological artifacts contain copper (Robbiola 1998). These metallic objects containing copper were corroded over time with the influence of $\mathrm{CuCl}$ (nantokite) formed by the reaction of copper with chloride compounds which called as "bronze disease". Furthermore, copper transforms into different compounds in the form of powder and completely disintegrates as a result of a series of reactions. For this reason, protection of the alloys 
consists of copper is very important. Copper degrades under environmental conditions by a series of reactions specified in (1), (2), and (3), respectively (Scott 1990).

Initially, copper oxidizes to copper ion;

$\mathrm{Cu} \rightarrow \mathrm{Cu}^{+}+\mathrm{e}^{-}$

Copper ion reacts with chloride ion to form an insoluble white-colored salt of copper chloride;

$\mathrm{Cu}^{+}+\mathrm{Cl}^{-} \rightarrow \mathrm{CuCl}$

Copper chloride reacts with moisture and oxygen readily existing in the environment;

$4 \mathrm{CuCl}+4 \mathrm{H}_{2} \mathrm{O}+\mathrm{O}_{2} \rightarrow 2 \mathrm{Cu}_{2}(\mathrm{OH})_{3} \mathrm{Cl}+2 \mathrm{HCI}$

This deterioration can be stopped by cleaning the surface of the historical artifact suffers from the bronze disease from the chloride ion and blocking the contact with oxygen and water.

Another metal frequently found in historical artifacts is silver. Silver readily forms alloys and most of it has intriguing electrical and mechanical properties. Silver items frequently used in ornaments, jewelry, food, and beverage containers, and various decorative objects as well as technological and medical purposes since ancient times. If the corrosion rate of silver-containing objects under different conditions were to be compared, objects recovered from underwater environments tend to corrode at the highest rate. This is followed by objects exposed to the indoor (higher relative humidity) and outdoor environment, respectively. The type and content of a silver alloy can be determined by examining the properties of the corrosion layer formed on the surface of the object. Objects containing silver usually react with sulfur to form acanthite, $\mathrm{Ag}_{2} \mathrm{~S}$ (4). A less common corrosion product is chlorargyrite, $\mathrm{AgCl}$ (5). Silver alloys produce the most reactive corrosion products among other alloyed metals. A commonly used type of silver alloy, sterling silver, usually consists of $92.5 \%$ silver and $7.5 \%$ copper by mass. The reduced sulfur readily found in the atmosphere will react with the copper portion of the sterling silver since it has a higher tendency to react and cause to corrode the object. The main corrosion product in silver and gold alloy is $\mathrm{Ag}_{2} \mathrm{~S}$. While the corrosion layer on the silver and zinc alloys contains $\mathrm{Ag}_{2} \mathrm{~S}, \mathrm{ZnO}$, and $\mathrm{ZnS}$, it will contain $\mathrm{Ag}_{2} \mathrm{~S}$ in a sulfur-rich environment with palladium-silver alloys and $\mathrm{PdCl}_{2}$ or $\mathrm{AgCl}$ in chloride rich environment (Christofer 2016).

$2 \mathrm{Ag}+\mathrm{S} \rightarrow \mathrm{Ag}_{2} \mathrm{~S}$

$\mathrm{Ag}+\mathrm{Cl} \rightarrow \mathrm{AgCl}$

Iron is another metal that has commonly found in historical artifacts as much as copper and silver. Iron corrodes in the presence of moisture and oxygen as a result of a series of reactions specified in (6), (7), (8), (9), and (10).

$$
\begin{aligned}
& \mathrm{O}_{2}+4 \mathrm{e}^{-}+2 \mathrm{H}_{2} \mathrm{O} \rightarrow 4 \mathrm{OH}^{-} \\
& \mathrm{Fe} \rightarrow \mathrm{Fe}^{2+}+2 \mathrm{e}^{-} \\
& 4 \mathrm{Fe}^{2+}+\mathrm{O}_{2} \rightarrow 4 \mathrm{Fe}^{3+}+2 \mathrm{O}^{2-} \\
& \mathrm{Fe}^{2+}+2 \mathrm{H}_{2} \mathrm{O} \rightleftharpoons \mathrm{Fe}(\mathrm{OH})_{2}+2 \mathrm{H}^{+} \\
& \mathrm{Fe}^{3+}+3 \mathrm{H}_{2} \mathrm{O} \rightleftharpoons \mathrm{Fe}(\mathrm{OH})_{3}+3 \mathrm{H}^{+} \\
& \mathrm{Fe}(\mathrm{OH})_{2} \rightleftharpoons \mathrm{FeO}+\mathrm{H}_{2} \mathrm{O} \\
& \mathrm{Fe}(\mathrm{OH})_{3} \rightleftharpoons \mathrm{FeO}(\mathrm{OH})+\mathrm{H}_{2} \mathrm{O} \\
& 2 \mathrm{FeO}(\mathrm{OH}) \rightleftharpoons \mathrm{Fe}_{2} \mathrm{O}_{3}+\mathrm{H}_{2} \mathrm{O}
\end{aligned}
$$

Another metal usually found in alloys is tin. Bronze, which was commonly used in ancient objects, is an alloy that consists of copper and tin. Tin is highly resistant to corrosion compared to other commonly used metals and for this reason, it was often used for the hardening of copper in ancient ages. However, tin can also corrode over time with the presence of oxygen and moisture to create $\mathrm{SnO}$ and $\mathrm{SnO}_{2}$ compounds.

Lead also has a centuries-old history like copper. Since it has a structure that allows being easily shaped by pounding, melting, or forging, lead alloys enabled to produce various objects. Lead also easily reacts with oxygen in the air and forms a very thin layer of lead oxide on the surface which is quite durable and hard to erode and thus it doesn't need a protective painting layer like iron. The oldest (6400 BC) known object containing lead is a necklace consists of copper and lead beads found in Çatalhöyük, Turkey (Radivojević vd. 2017). The Roman Empire was the largest producer of the lead in the ancient world, they have used lead intensely in sculptures, ornaments, the coloring of glasses (Molina vd. 2014), sweetening wine and food, water pipes (grooves), coins, plates, cosmetics, and many other everyday items. So much so that the data of atmospheric lead pollution in the ice sheets of Greenland coincide with the growth and decline periods of the Roman Empire (Terpstra vd. 2019).

Some metals are prone to corrosion more than others. The reason for this is that the metal species have different reactivities. Also, a phenomenon called galvanic corrosion occurs when two metals are in contact (in the form of alloy, coating, or solder) in a humid environment. In other words, even if the metal has a low reactivity against corrosion, it starts to corrode from the contact point with the other metal having high reactivity. For example, when aluminum rivets were used to combine copper parts, copper would start to corrode from the contact point with the effect of moisture as an electrolyte. Table 2 shows the corrosion rates of commonly used metals in seawater. Another example would be tin plates, which are stable when coated but in case of dents or stratches on the surface, iron content begins to galvanically corrode in the presence of moisture in the substrate. 
Table 2. Reactivity of commonly used metals (in seawater)

\begin{tabular}{|c|c|}
\hline Metal & \multicolumn{2}{c|}{ Notes } \\
\hline Platinum \\
\hline Gold \\
\hline Silver \\
\hline Nickel \\
\hline Lead \\
\hline Copper-nickels
\end{tabular}

Table 3. Types of corrosion on various metal types and their effects, H, high sensitivity; L, low sensitivity; M, moderate sensitivity; N, no sensitivity (Christofer 2016).

\begin{tabular}{lcccccccc}
$\begin{array}{l}\text { Corrosive } \\
\text { Species }\end{array}$ & $\mathrm{Ag}$ & $\mathrm{Al}$ & $\mathbf{C u}$ & $\mathrm{Fe}$ & $\mathbf{N i}$ & $\mathbf{P b}$ & $\mathrm{Sn}$ & $\mathbf{Z n}$ \\
\hline $\mathbf{C O}_{2} / \mathrm{CO}_{3}{ }^{2-}$ & $\mathrm{L}$ & $\mathrm{N}$ & $\mathrm{N}$ & $\mathrm{M}$ & $\mathrm{L}$ & $\mathrm{M}$ & $\mathrm{N}$ & $\mathrm{M}$ \\
$\mathbf{N H}_{3} / \mathrm{NH}_{4}{ }^{+}$ & $\mathrm{M}$ & $\mathrm{L}$ & $\mathrm{M}$ & $\mathrm{L}$ & $\mathrm{L}$ & $\mathrm{L}$ & $\mathrm{L}$ & $\mathrm{L}$ \\
$\mathbf{N O}_{2} / \mathrm{NO}_{3}{ }^{-}$ & $\mathrm{N}$ & $\mathrm{L}$ & $\mathrm{M}$ & $\mathrm{M}$ & $\mathrm{M}$ & $\mathrm{M}$ & $\mathrm{L}$ & $\mathrm{M}$ \\
$\mathbf{H} \mathbf{S}$ & $\mathrm{H}$ & $\mathrm{L}$ & $\mathrm{H}$ & $\mathrm{L}$ & $\mathrm{L}$ & $\mathrm{L}$ & $\mathrm{L}$ & $\mathrm{L}$
\end{tabular}

$\begin{array}{lllllllll}\mathbf{S O}_{2} / \mathbf{S O}_{4}{ }^{2-} & \mathrm{L} & \mathrm{M} & \mathrm{H} & \mathrm{H} & \mathrm{H} & \mathrm{M} & \mathrm{L} & \mathrm{H} \\ \mathbf{H C l} / \mathbf{C l}^{-} & \mathrm{M} & \mathrm{H} & \mathrm{M} & \mathrm{H} & \mathrm{M} & \mathrm{M} & \mathrm{M} & \mathrm{M}\end{array}$

$\begin{array}{lllllllll}\mathbf{R C O O H} / & \mathrm{L} & \mathrm{L} & \mathrm{M} & \mathrm{M} & \mathrm{M} & \mathrm{H} & \mathrm{L} & \mathrm{M} \\ \mathbf{C O O H}^{-} & \mathrm{M} & \mathrm{N} & \mathrm{M} & \mathrm{M} & \mathrm{M} & \mathrm{M} & \mathrm{L} & \mathrm{M} \\ \mathbf{O}_{3} & \mathrm{M} & & \end{array}$

Nowadays, the release of corrosive gases to the atmosphere is increasing as a result of developing technology and industrialization. The species readily found in environmental conditions that causing corrosion and their effects are shown in Table 1.3. The gases that accelerate the corrosion of metals (Christofer 2016);

- Ammonia, $\mathrm{NH}_{3}$ (Agricultural activities such as usage of synthetic fertilizers and current methods of raising livestock increase its amount in the atmosphere.)

- Nitrogen dioxide, $\mathrm{NO}_{2}$ (The amount in the atmosphere increases as a result of burning fossil fuels.)

- Sulfur dioxide, $\mathrm{SO}_{2}$ (The amount in the atmosphere increases as a result of the burning of fossil fuels containing sulfur.)

- Hydrochloric Acid, $\mathrm{HCl}$ (It is formed as a result of the reaction of $\mathrm{HNO}_{3}$ or $\mathrm{H}_{2} \mathrm{SO}_{4}$ with chlorine in the sea, usually due to industrialization in coastal areas. It is also formed by the dissolution of $\mathrm{NO}_{2}$ and $\mathrm{SO}_{2}$ gases in sea water.)

- Carbondioxide, $\mathrm{CO}_{2}$ (It causes to formation of carbonic acid which is not as much corrosive compared to other gases. However, it increases the emission of other harmful gases due to global warming.)

- Ozone, $\mathrm{O}_{3}$ (Its amount is associated with emissions of $\mathrm{NO}_{2}$ and other volatile organic carbon compounds. It generally increases the corrosion rate of metals, especially yellowcolored metals (Yang 1993).

Figure II shows the the estimates for increasing amount of anthropogenic $\mathrm{CO}_{2}$ and other major air pollutants between 2010 - 2030. As can be seen from the graphics, the amount of corrosive species is increasing in general.

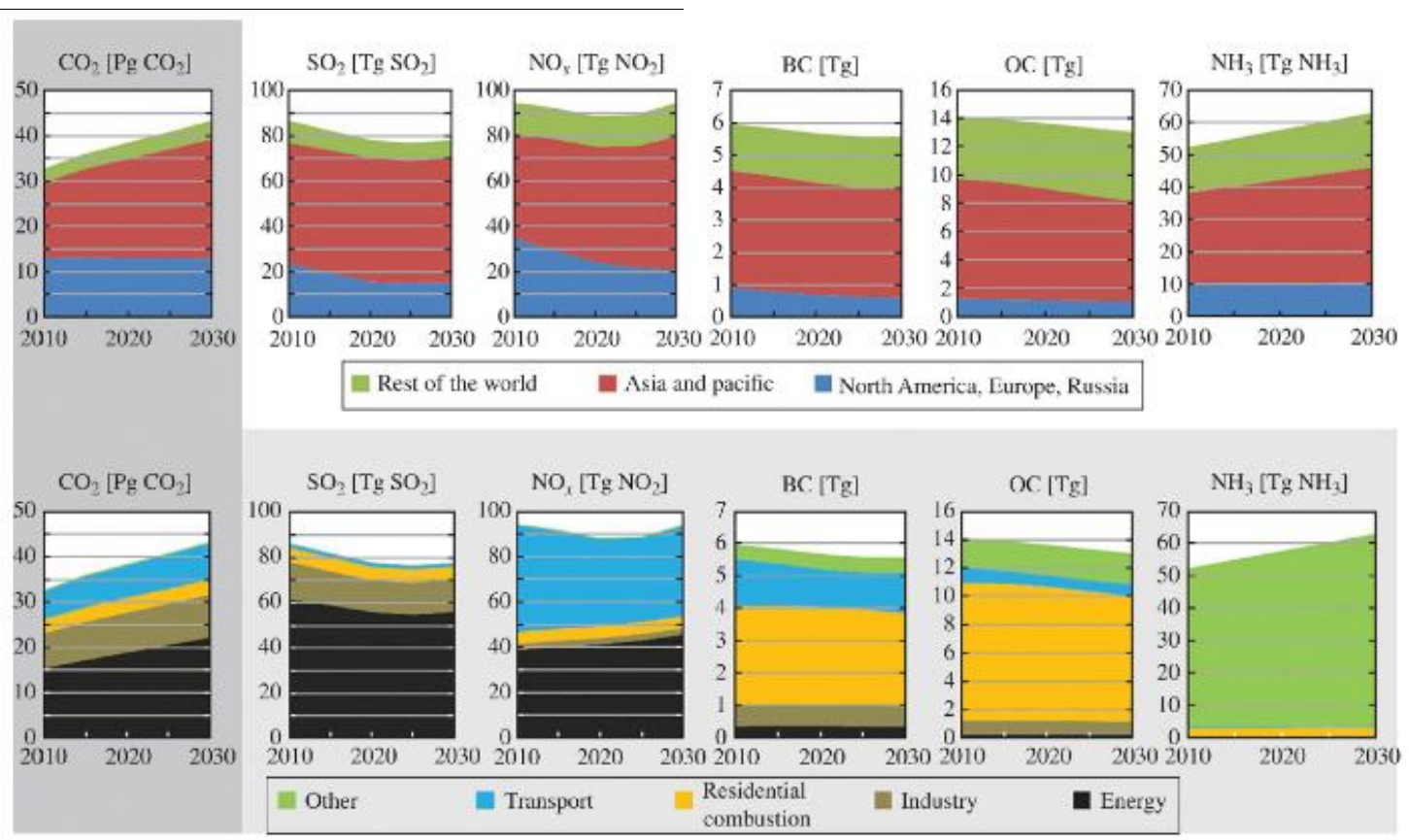

Fig.2. Estimates of anthropogenic $\mathrm{CO}_{2}$ and major air pollutants increase between 2010 and 2030, NOx: nitrogen oxides, BC: carbon black, OC: organic carbon, Pg: petagram, Tg: teragram (Christofer 2006). 
Metal surfaces will corrode even more rapidly with the increase of harmful gases in the atmosphere in the following years. Considering the environmental factors and varying corrosive properties of different metal types, it is very important to cover the surfaces of ancient artifacts with a surface-specific protective layer in order to delay the corrosion process (Wilson 2019).

\section{Widely Used Methods to Prevent Corrosion}

Novel and more effective coating types are being developed for metal-containing ancient artifacts by using the procedure schematized in Figure III. It is very important that the protective layer shouldn't easily be affected by external factors such as heat, light, moisture and its chemical structure shouldn't damage the surface and cause a change in color. Traditional chemicals that have long been used for corrosion protection had many disadvantages. For example, since ancient times, metalcontaining objects were sometimes covered with wax (Moffett 1996). These wax coatings were acting as a barrier to keep moisture and oxygen out from the metal but they also had some disadvantages. They had low durability, nonpolar contaminants were able to easily diffuse onto them, and weren't constitute an obstacle for microorganisms that may damage the object.

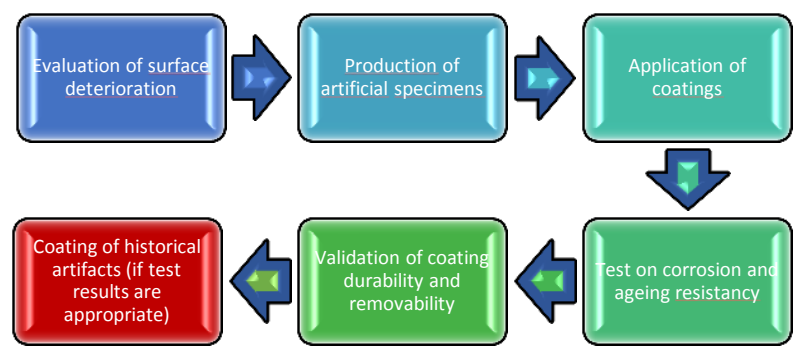

Fig. 3. Corrosion-protective coating procedure for metalcontaining historical objects

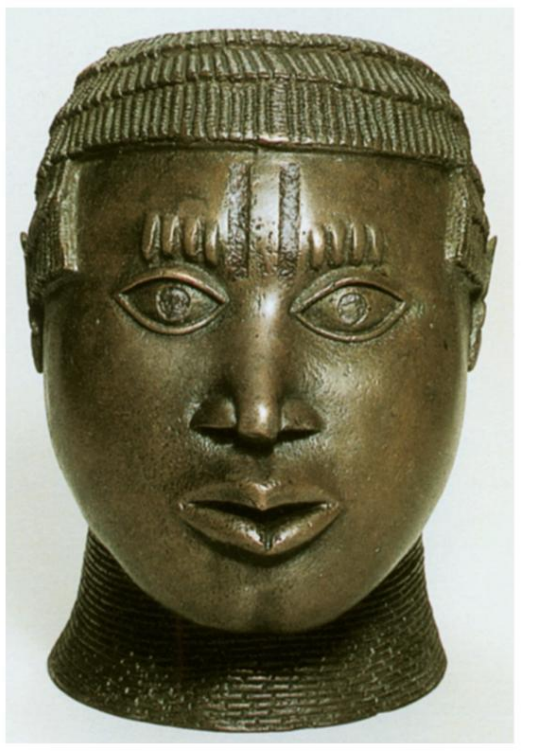

Fig. 4. A Benin commemorative figure coated with wax Nowadays, wax formulations that incorporated with compounds such as Incralac (benzotriazole, methyl methacrylate copolymer) are used to prevent contaminants from penetrating the porous surface towards the underlayer and causing surface erosion. For example, Figure IV shows a Benin commemorative figure made of bronze which is coated with two layers of Incralac and one finish layer of Renaissance wax (microcrystalline-polyethylene wax mixture). The mechanical strength of the coating found to be very low and open to be highly affected by environmental conditions (Moffett 1996). Another example would be Paraloid B-72 (Figure V.) resin that consists of ethyl methacrylate (\%70 wt.) and methyl acrylate copolymer (\%30 wt.) which is widely used for protection and repair, and also effective against corrosion (Feller 1972). Acrylic resins such as polyvinyl acetate (PVAc) emulsions and PrimalAC-33 compounds are also widely used for protection purposes. Although these resins are widely preferred on various surfaces such as metal, glass, and wood, it has been found that with time they damage the surface at a higher rate compared to corrosion (Koop 2009). In addition, these acrylic resins undergo photo-oxidation reactions induced by the effect of sunlight and tend to degrade even faster with temperature and atmospheric pollution. The coating starts to turn yellow over time due to photooxidation reactions and it becomes unable to protect the surface from external factors. Even more, these coatings become so unstable as they start to crack over time with the effect of light and heat (Davison 1984, Winther 2015).<smiles>CCOC(=O)C(C)(CC(C)(C)C)C(C)(CC(C)(C)C1CCCC1)C(=O)OC</smiles>

Fig.5. Chemical structure of Paraloid B72

Plasma polymer coatings were tried about 10 years ago for protection in metal archaeological artifacts. Nanoscaled $(5-50 \mathrm{~nm})$ polymer coatings were successfully applied on different types of nails (stainless steel, $\mathrm{Fe}, \mathrm{Cu}$, $\mathrm{Ag}$ ) from the Roman Era. Although the coating shows high resistance to corrosion, discoloration was observed in some areas and it didn't adhere well to silver surfaces. Although it is a method that can be used against corrosion for most types of metals, its experimental procedures are long, tedious, and expensive (Favrequattropani 2000).

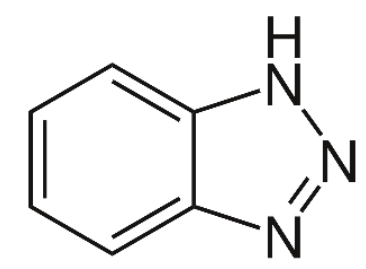

Fig.6. Chemical structure of Benzotriazole 
It is common to coat metal surfaces with heterocyclic compounds containing nitrogen prepared in acidic solutions to protect them from corrosion. Azole compounds (thiazole, benzotriazole, imidazole, and thiadiazole), amines, and Schiff bases can be mentioned among some of the important and commonly used corrosion inhibitors in the protection of tin, zinc, copper lead, and their alloys. Benzotriazole (BTA), which is one of the azole derivatives and has the chemical structure of $\mathrm{C}_{6} \mathrm{H}_{5} \mathrm{~N}_{3}$ (Figure VI.), is known as a very effective corrosion inhibitor that especially used against chlorides for the protection of copper and its alloys (Hollander, 1985). Even though BTA has a lower toxic effect than some anti-corrosion organic compounds, it still has a damaging effect on the skin and eyes (Stupnišek-Lisac 1998, Finšgar 2010). In addition, BTA and its derivatives considered to be effective and stable corrosion inhibitors for copper in neutral and alkaline mediums but they can't protect the metal surface due to their dissolution in acidic conditions (Khan 2015, Tromans 1991).

There are also environmentally friendly natural coatings used other than wax to prevent corrosion. These components are also widely used because of their antifungal, antibacterial, and non-toxic effects. Plant extracts and oils are preferred among natural protective coatings (Behpour 2012). Also, there are formulations in which amino acids (cysteine derivatives, methionine, glycine, tannin or isatin) are used as corrosion inhibitors (Moretti 2002, Zhang 2010, Barouni 2014, Makarenko 2011). Amino acids tend to produce complexes with metal surfaces so to act as corrosion inhibitors. However, the protection capability of these coatings is short-lived and can be easily removed from the surface.

In some research, protection against corrosion was provided by an ultra-thin organic film containing polypyrrole or polyaniline that forms conductive polymer film on metal surfaces. However, since most of the electro synthesizable polymer films are not optically transparent, the selection of monomers to be used in historical artifacts is limited. Still, it has been determined that the coating of an aluminum metal object with poly(3-octylpyrrole) compound and coating of copper, bronze, and silver objects with poly(3-amino-1,2,4,triazole) compound has been found to show positive results against corrosion. In addition, carboxylate groupcontaining compounds or their derivatives have also been tried to protect metal-containing heritage artifacts from corrosion. It has been determined that carboxylates are non-oxidizing inhibitors and therefore provide partial protection (Abrantes 2013).

Historical artifacts containing metals can also be preserved using nanotechnology. Studies in this area are considered new and promising. Studies have been made with nanotechnology to reduce cracks inside the artifacts, increase mechanical strength, increase chemical resistance, protect the surface against UV rays, and/or change its hydrophobic character or porous size distribution (Fiqueira 2014).

\section{Summary}

It is necessary to know the type of metal or metals in the object to repair and protect since the protective coating will be determined according to that knowledge. Various methods based of different materials such as waxes, oils and greases, polymers, glasses and glassy enamels, metallic, and organic coatings have been used to develop corrosion-resistant coatings for centuries. Each of these aforementioned methods has its own disadvantages. Nanotechnological methods that have been used lately for archaeological artifacts are very promising. The importance of new studies in this field is gradually increasing when compared to other traditional methods, especially due to the ability to obtain an infinite variety of molecules with silicon chemistry and the ease of transition between organic and inorganic structures (hybrid materials).

\section{References}

Abrantes, L. M., Melato, A. I. 2013. Corrosion and Conservation of Cultural Heritage Metallic Artefacts. European Federation of Corrosion (EFC) Series. Pages 518-539. University of Lisbon, Portugal.

Barouni, K., Kassale, A., Albourine, A., Jbara, O., Hammouti, B., Bazzi, L., 2014. Amino acids as corrosion inhibitors for copper in nitric acid medium: Experimental and theoretical study. J. Mater. Environ. Sci., 5(2), 456-463.

Behpour, M., Ghoreishi, S.M., Khayatkashani, M., Soltani, N., 2012. Green approach to corrosion inhibition of mild steel in two acidic solutions by the extract of Punica granatum peel and main constituents. Materials Chemistry and Physics, 131(3), 621-633, doi. 10.1016/j.matchemphys. 2011.10.027.

Black, L. and Allen, G.C. 1999. "Nature of lead patination" Brit. Corros. J., 34(3), 192-197, doi. 10.1179/000705999101500833

Christofer, L.; Odnevall, W.I.; Johan, T,; Thomas, G. 2016. Atmospheric Gases And Therr Involvement In Corrosion. Atmospheric Corrosion (2nd ed.), 34-45. Wiley, doi.10.1002/9781118762134.ch4

Davison, S. 1984. "A review of adhesives and consolidants used on glass antiquities." Stud. Conserv. 29(sup1), 191-194. Do1.10.1179/sic.1984.29.supplement-1.191

Favre-quattropani, L., Groening, P., Ramseyer, D., Schlapbach, L. 2000. The protection of metallic archaeological objects using plasma polymer coatings. Surf. Coat. Technol. 125(1-3), 377-382, doi.10.1016/s0257-8972(99)00579-4

Feller, R. L., Stolow and N. Jones, E. H. 1972. On Picture Varnishes and their Solvents, Case Western Reserve University, Cleveland.

Figueira, R. B., Silva, C. J. R., Pereira, E. V., 2014. Organic-inorganic hybrid sol-gel coatings for metal corrosion protection: a review of recent progress. $J$. Coat. Technol. Res., 12(1), 1-35, doi.10.1007/s11998-014-9595-6

Finšgar, M., Milošev, I., 2010. Inhibition of copper corrosion by 1, 2, 3-benzotriazole: a review. 
Corrosion science, 52(9), 2737-2749, doi.10.1016/j.corsci.2010.05.002

Hollander, O., May, R.C., 1985. The chemistry of azole copper corrosion inhibitors in cooling waters. Corrosion, 41(1), 39-45, doi.10.5006/1.3581967

Khan, P.F., Shanthi, V., Babu, R.K., Muralidharan, S., Barik, R.C., 2015. Effect of benzotriazole on corrosion inhibition of copper under flow conditions. Journal of Environmental Chemical Engineering, 3(1), 10-19, doi.10.1016/j.jece.2014.11.005

Kolasinski, K. W. 2012. Surface and Adsorbate Structure. Surface Science: Foundations of Catalysis and Nanoscience. John Wiley \& Sons, New York, John Wiley and Sons, doi.10.1002/ 9781119941798.ch1

Koob, P. Stephen, "Paraloid B-72®: 25 years of use as a consolidant and adhesive for ceramics and glass", Holding It All Together: Ancient and Modern Approaches to Joining, Repair and Consolidation, (Ed. J. Ambers, C. Higgitt, L. Harrison, and D. Saunders), Londra, 2009, 113-119.

Lyklema, J. 2001. Fundamentals of Interface and Colloid Science (vol. I). New York, Academic Press.

Makarenko, N., Kharchenko, U., Zemnukhova, L., 2011. Effect of amino acids on corrosion of copper and steel in acid medium. Russian Journal of Applied Chemistry 84(8), 1362-1365, doi.10.1134/ s1070427211080118

Moffett, D. L. 1996. Wax Coatıngs On Ethnographic Metal Objects: Justifications For Allowing A Tradition To Wane. Journal of the American Institute for Conservation, 35(1), 1-7, doi.10. 1179/019713696806124557

Molina, G., Odin, G. P., Pradell, T., Shortland, A. J., \& Tite, M. S. (2014). Production technology and replication of lead antimonate yellow glass from New Kingdom Egypt and the Roman Empire. Journal of Archaeological Science, 41, 171-184, doi.10.1016/j.jas.2013.07.030

Moretti, G., Guidi, F., 2002. Tryptophan as copper corrosion inhibitor in $0.5 \mathrm{M}$ aerated sulfuric acid. Corrosion science, 44(9), 1995-2011, doi.10.1016 /s0010-938x(02)00020-3

Radivojević, M.; Rehren, T.; Farid, S.; Pernicka, E.; Camurcuoğlu, D. (2017). Repealing the Çatalhöyük extractive metallurgy: The green, the fire and the "slag." Journal of Archaeological Science, 86, 101122, doi.10.1016/j.jas.2017.07.001

Robbiola, L.; Blengino, J.M.; Fiaud, C. 1998. Morphology and mechanisms of formation of natural patinas on archaeological $\mathrm{Cu}-\mathrm{Sn}$ alloys. Corros. Sci., 40(12), 2083-2111, doi.10.1016/s0010-938x (98)00096-1

Scott, David A. (1990). Bronze Disease: A Review of Some Chemical Problems and the Role of Relative Humidity. Journal of the American Institute for Conservation. 29(2), 193-206, doi. 10.1179/ 019713690806046064

Stupnišek-Lisac, E., Bozic, A.L., Cafuk, I., 1998. Lowtoxicity copper corrosion inhibitors. Corrosion, 54(9), 713-720, doi.10.5006/1.3284890
Terpstra, T. (2019). Roman Technological Progress in Comparative Context: The Roman Empire, Medieval Europe and Imperial China. Explorations in Economic History, 101300, doi.10.1016/ j.eeh.2019.101300

Tromans, D., Sun, R.h., (1991). Anodic polarization behavior of copper in aqueous chloride/benzotriazole solutions. Journal of the Electrochemical Society, 138(11), 3235-3244, doi.10.1149/1.2085397

Winther, T. Bannerman, J., Skogstad, H., Johansson, M. K. G., Jacobson, K. and Samuelsson, J. (2015). Adhesives for adhering polystyrene plastic and their long-term effect. Studies in Conservation, 60(2):107120, doi.10.1179/2047058413Y.0000000105

Wilson, H. and Erbe, A. (2019). Convection induced by illumination-based metal surface heating increases corrosion potential, corrosion rates. Electrochemistry Communications, 106,106513, doi. 10.1016/ j.elecom.2019.106513

Yang, B; Johnson, D A; Shim, S H. (1993). Effect of ozone on corrosion of metals used in cooling towers. Corrosion, 49(6): 499-513, doi.10.5006/1.3316079

Zhang, D.Q., Gao, L.X., Cai, Q.R., Lee, K., (2010). Inhibition of copper corrosion by modifying cysteine self-assembled film with alkylamine/alkylacid compounds. Materials and corrosion, 61, 16-21, doi.10.1002/maco.200905225. 